\title{
A note on absorption of crystalline threonine in pigs*
}

\author{
L. Buraczewska and E. Święch \\ The Kielanowski Institute of Animal Physiology and Nutrition, \\ Polish Academy of Sciences \\ 05-110 Jabtonna, Poland
}

(Reccived 25 April 2000; accepted 15 July 2000)

\begin{abstract}
Two groups of 6 castrated pigs, in which each animal weighed $44 \mathrm{~kg}$ and was equipped with a post-valvular T-caecum cannula, were given threonine-deficient and threonine-supplemented $(0.1 \%)$ diets. As similar daily flows of $\mathrm{N}$ and threonine were found in the ileal digesta after feeding both diets, it is concluded that crystalline threonine added to cereal-based diets is entirely absorbed in the small intestine of pigs.
\end{abstract}

KEY WORDS: threonine, absorption, pigs

\section{INTRODUCTION}

Increasing quantities of crystalline amino acids are being used to supplement diets for pigs. Yen et al. (1991) found that pigs absorb free lysine and threonine more rapidly than protein-bound lysine and threonine.

Our previous study of amino acid absorption in the small intestine (Buraczews$\mathrm{ka}, 1981$ ) demonstrated that the rate of absorption of free threonine, similarly to histidine, was lower as compared with other free essential amino acids, and depended on the concentration of amino acids in the intestine.

The objective of the present study was to determine whether crystalline threonine is absorbed completely in the small intestine after feeding pigs with a threonine-supplemented diet.

* Supported by the Committee for Scientific Research, Grant No 5 PO6 E 00113 


\section{MATERIAL AND METHODS}

Diets

Threonine-deficient and threonine-supplemented diets consisted of $(\mathrm{g} / \mathrm{kg})$ : wheat 763, lupin 150 , soyabean meal 50 , vitamin-mineral mixture $30, \mathrm{Cr}_{2} \mathrm{O}_{3} 3$, lysine $\mathrm{HCl} 3.4$, and methionine 0.6 . To the supplemented diet $0.1 \%$ crystalline L-threonine was added. The diets contained $177 \mathrm{~g}$ crude protein and $13.1 \mathrm{MJ}$ ME per kg.

\section{Animals}

Twelve castrated male pigs (line 990), surgically fitted with post-valvular T-caecum cannulae according to van Leeuwen et al. (1991) were divided into two groups and fed with the respective diets for 12 days. The pigs were kept in metabolic cages and given two equal portions of the diets at $08: 00$ and 20:00 h. The diets were mixed with water (1:1) just before feeding and offered to the pigs in amounts 3.0 times the maintenance requirements for energy $\left(1.5 \mathrm{MJ} \mathrm{ME} / \mathrm{kg} \mathrm{BW}^{0.75}\right)$.

\section{Experimental procedure}

At the end of feeding the experimental diets, when the animals were at about $53 \mathrm{~kg}$ body weight, ileal digesta was collected for 3 days, $12 \mathrm{~h}$ a day (between 08:00 and 20:00). The collection was carried out by attaching plastic bags to the cannulae. The bags were changed every hour and their contents immediately frozen at $-20^{\circ} \mathrm{C}$. After completion of the collection the samples were thawed, pooled per animal within the experimental period, frecze-dricd and ground before chemical analysis.

\section{Chemical analysis}

Dry matter and nitrogen were analysed using standard methods (AOAC, 1990). Threonine was determined in HCl-hydrolysed digesta using a Beckman 6300 high pressure amino acid analyser. Chromium oxide was determined according to the Kimura and Miller (1957) procedure.

\section{RESULTS AND DISCUSSION}

Both nitrogen and threonine concentrations in the digesta were similar after feeding the threonine-deficient and thrconine-supplemented dicts (Table 1). This means that the added free threonine disappeared completely from the lumen of the 
TABLE 1

Nitrogen $(\mathrm{N})$ and thrconine (Thr) content in the ileal digesta, and ilcal apparent digestibility of the nutrients after feeding pigs with Thr-deficient and Thr-supplemented diets

\begin{tabular}{|c|c|c|c|}
\hline & \multicolumn{2}{|c|}{ Diets } & \multirow{3}{*}{$P<0.05$} \\
\hline & Thr-deficient & Thr-supplemented & \\
\hline & $\overline{\mathrm{X}} \quad \mathrm{SD}$ & $\overline{\mathrm{X}} \quad \mathrm{SD}$ & \\
\hline Nitrogen, \% DM & $2.33 \pm 0.12$ & $2.41 \pm 0.10$ & ns \\
\hline Threonine, $\mathrm{g} / 16 \mathrm{gN}$ & $3.95 \pm 0.08$ & $3.85 \pm 0.09$ & ns \\
\hline DM digestibility, \% & $70.71 \pm 1.03$ & $71.39 \pm 0.56$ & ns \\
\hline $\mathrm{N}$ digestibility, \% & $78.70 \pm 1.50$ & $79.39 \pm 0.75$ & ns \\
\hline Thr digestibility, $\%$ & $70.19 \pm 2.02$ & $71.60 \pm 0.88$ & ns \\
\hline
\end{tabular}

1 caiculation is based on the content of protein-bound threonine in the diets

small intestine. Consequently, ileal digestibility of protein-bound threonine was similar after feeding both diets. Also, no differences were observed in the digestibility of dry matter or crude protein of the diets.

The results point to $100 \%$ ileal digestibility of crystalline threonine in pig diets. However, more rapid absorption of free- than protein-bound threonine (Yen et al., 1991) may affect the utilisation efficiency of the free amino acid, which was shown in experiments with different frequencies of feeding diets supplemented with free lysine (Buraczewski and Buraczewska, 1980; Batterham and Murison, 1981; Cook et al., 1985). It is suggested that feeding more meals (also ad libitum feeding) is more efficient since it may prevent an imbalance of amino acids at the site of protein synthesis resulting from more rapid absorption of free amino acid(s) such as lysine or threonine.

\section{REFERENCES}

AOAC, Association of Official Chemists, 1990. Official Methods of Analysis of the Association of Official Analytical Chemists. 15th Edition. Chapter 32. Washington, DC

Batterham E.S.. Murison R.D., 1981. Utilization of free lysine by growing pigs. Brit. J. Nutr. 46, $87-92$

Buraczewska L., 1981. Abssorption of amino acids in different parts of the small intestine in growing pigs. J. Absorption of free amino acids and water. Acta Physiol. pol. 32, 419-428

Buraczewska L., Buraczewski S., 1980. Protein utilization of diets supplemented with free lysine or protein concentrate in pigs fed one or four meals daily. Procecdings of the 3rd EAAP Symposium on Protein Metabolism and Nutrition, Braunschweig (Germany), Publication No 27, Vol. 1, pp. $307-311$

Cook H., Giesting D.W., Easter R., 1985. The influence of feeding frequency and crystallinc lysine supplementation on performance of linisher pigs. J. Anim. Sci. 61. Suppl, 1, 319 (Abstr.) 
Kimura F.T., Miller V.L., 1957. Improved determination of chromic oxide in cow feed and facces. J. Agr. Food Chem. 5, 216

Van Lecuwen P., van Kleef D.J., van Kempen G.J.M., Huisman J., Verstegen M.W.A., 1991. The post valve $\mathrm{T}$-caecum cannulation technique in pigs applicated to determine the digestibility of amino acids in maize, groundnut and sunflower meal. J. Anim. Physiol. Anim. Nutr. 65, 183-193

Yen J.T., Easter R.A., Kerr B.J., 1991. Absorption of free or protein-bound lysine and threonine in conscious multicannulated pigs. Proceedings of the Vth International Symposium on Digestive Physiology in Pigs, Wageningen (The Netherlands), EAAP Publication, No 54, pp. 79-84

\section{STRESZCZENIE}

\section{Wchlanianie krystalicznej treoniny przez świnie}

Dwic grupy wieprzków, po 6 sztuk, ważących średnio $44 \mathrm{~kg}, \mathrm{z}$ prostą przetoką w zredukowanym jelicie ślepym, żywiono przez 12 dni dwiema mieszankami składającymi się z takich samych składników podstawowych (pszenica, łubin. śruta sojowa), ale różniącymi się zawartością treoniny. Mieszanka niedoborowa w ten aminokwas zawierała tylko treoninę związaną w białku paszy, druga była uzupełniona treonina krystaliczną $(0,1 \%)$. Po 9 dniach żywienia mieszankami, przez kolejne 3 dni zbierano treść pokarmową przez przetoki ( 12 godz/dzień). Na podstawie zawartości azotu i treoniny w treści można wyciagnąć wniosek, że krystaliczna treonina uzupełniająca mieszankç została całkowicie wchłonięta w jelicie cienkim świń. Strawność pozorna treoniny związanej w białku nie różniła się między mieszankami i wynosiła średnio $71 \%$. 